\title{
Value of useful goods and ecosystem services from Agnalavelo sacred forest and their relationships with forest conservation
}

Tabita N. Randrianarivony',", Tefy H. Andriamihajarivol, Aro V. Ramarosandratana", Fortunat Rakotoarivony!, Vololoniaina H. Jeannoda", Alyse Kuhlman"'I, Armand Randrianasololv, Rainer Bussmann Iv

\begin{abstract}
Agnalavelo forest provides necessary natural resources to people who live in its surroundings (Communities of Mahaboboka, Amboronabo and Mikoboka in southwestern Madagascar). The aim of this study is to document goods and ecosystem services provided by Agnalavelo forest to local people and to use it as a tool for the identification of priorities for forest conservation. Oral interviews were undertaken from 2010-2013 with local communities living in the vicinity of Agnalavelo forest. This study also investigated forest resource use, conducted inventories of tree species, estimated wood biovolume, as well as the economic benefits associated with conservation due to carbon storage. Finally, we recorded felled trees caused by honey collection inside the forest and determine the cause for their slaughter. An investigation with the ownership of rice fields irrigated by rivers taking sources from Agnalavelo forest was also conducted. Based on field surveys and analysis, communities living around Agnalavelo forest draw substantial benefits for their daily life from the forest. Goods and ecosystem services are classified in the three categories (provisioning, cultural and regulating services) according to the Millennium Ecosystem Assessment (MEA). Cultural services are highly valuable to local people as the forest is a dwelling place for their ancestor's spirits. Agnalavelo forest provides Non Wood Forest Products (NWFPS) such as foods, tools, magic and medicinal plants and fresh water for local people. It is able to store 152 tons of carbon per hectare which is very important for climate regulation in this dry southwestern part of Madagascar. Endemic tree species hosting bee hives are often felled during harvesting period. Agnalavelo forest conservation is very important not only with regards to its biodiversity but also for goods and services that it provides to local population.
\end{abstract}

\author{
Correspondence: \\ Tabita N. Randrianarivony \\ Missouri Botanical Garden, \\ Madagascar Research and Conservation Program, \\ BP 3391, Antananarivo 101, Madagascar \\ Email: tabivony2001@yahoo.fr
}

\section{RÉSUMÉ}

La forêt d'Agnalavelo, sur les communes de Mahaboboka, Amboronabo et Mikoboka, au sud-ouest de Madagascar, fournit les ressources naturelles nécessaires pour la population riveraine. L'objectif de cette étude a été de documenter les biens et les services éco-systémiques fournis par la forêt d'Agnalavelo pour les populations locales, afin d'identifier les priorités pour la conservation de cette forêt. Des enquêtes auprès des communautés vivant à proximité de la forêt Agnalavelo ont été menées, entre 2010 et 2013, sur I'utilisation des ressources forestières. Des inventaires écologiques des espèces d'arbres forestiers utilisés ont été réalisés pour déterminer le biovolume ainsi que les bénéfices économiques associés à la conservation de la forêt d'Agnalavelo par le stockage de carbone. Un inventaire des arbres abattus le long d'une piste forestière et les causes de leurs abattages ont complété l'étude, ainsi que des enquêtes auprès des propriétaires des rizières irriguées par les rivières qui prennent leurs sources dans la forêt d'Agnalavelo qui ont révélé que les communautés riveraines en tirent profit dans leur quotidien. La forêt d'Agnalavelo offre trois catégories de biens et services écosystémiques, à savoir les services d'approvisionnement, les services culturels et les services de régulation. Les services culturels sont les plus importants pour la population locale. La forêt d'Agnalavelo fournit les produits forestiers non ligneux tels que de la nourriture, des outils, des plantes considérées comme magiques, des plantes médicinales et de l'eau douce pour la population locale. La forêt d'Agnalavelo peut stocker 152 tonnes de carbone par hectare, valeur importante pour la régulation du climat dans cette région sèche de Madagascar. Des arbres appartenant à des espèces endémiques de Madagascar et abritant des ruches sont souvent abattus lors de la récolte du miel. La conservation de la forêt d'Agnalavelo est importante aussi bien pour la biodiversité qu'elle héberge que pour les biens et services des écosystèmes qu'elle fournit à la population locale.

\footnotetext{
I Missouri Botanical Garden, Madagascar Research and Conservation Program, BP 3391, Antananarivo 101, Madagascar

II Department of Plant Biology and Ecology, Faculty of Science, University of Antananarivo, BP 566, Antananarivo 101, Madagascar

III Department of Anthropology, Washington University, St. Louis, MO 63130-4899, USA

IV William L. Brown Center, Missouri Botanical Garden, P.O. Box 299, St. Louis, MO 63166-0299, USA

Citation Randrianarivony, T. N., Andriamihajarivo, T. H., Ramarosandratana, A. V., Rakotoarivony, F., Jeannoda, V. H., Kuhlman, A., Randrianasolo, A. and Bussmann

R. 2016. Value of useful goods and ecosystem services from Agnalavelo sacred forest and their relationships with forest conservation. Madagascar Conservation \& Development 11, 2: 44-51 http://dx.doi.org.104314/mcd.v11i2.1
} 


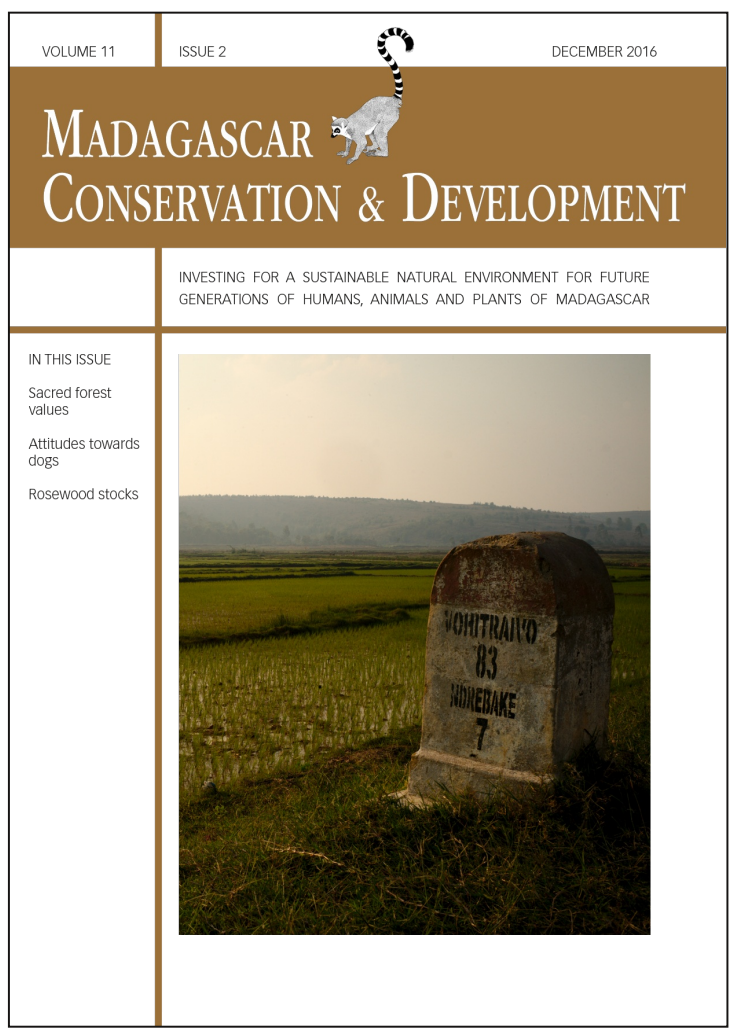

Madagascar Conservation \& Development is the journal of Indian Ocean e-Ink. It is produced under the responsibility of this institution. The views expressed in contributions to MCD are solely those of the authors and not those of the journal editors or the publisher.

All the Issues and articles are freely available at http://www.journalmcd.com

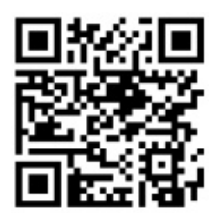

Contact Journal MCD

info@journalmcd.net for general inquiries regarding MCD funding@journalmcd.net to support the journal

Madagascar Conservation \& Development Institute and Museum of Anthropology

University of Zurich

Winterthurerstrasse 190

$\mathrm{CH}-8057$ Zurich

Switzerland

Indian Ocean e-Ink

Promoting African Publishing and Education

www.ioeink.com

Missouri Botanical Garden (MBG)

Madagascar Research and Conservation Program BP 3391

Antananarivo, 101, Madagascar 


\section{BACKGROUND}

Forests make significant direct and indirect contributions to human welfare (Wu et al. 2010). Globally, nearly 1.6 billion people rely on forest goods and services (Vedeld et al. 2007). The concept of ecosystem services, defined as benefits people draw from ecosystems (Westman 1977, World Resources Institute 2003), was developed to better understand the interdependence between ecosystems and societies.

In Madagascar, one of the mega-diverse countries in the world (Mittermeier et al. 2005), about $80 \%$ of the population lives in rural areas (UNESCO 2012). Malagasy people are heavily dependent on natural resources for food, shelter, health care, clothing and tools (Sarrasin and Ramahatra 2006). There have been several recent attempts to estimate carbon stocks in Malagasy forests and their value, e.g., the Makira project in the North (Chappelle 2013), in Zahamena Mantadia (Wendland et al. 2010), in Menabe (Sommerville et al. 2010) and in Tsitongambarika (Olsen et al. 2011).

Before Agnalavelo was established as a New Protected Area (NPA), it was considered a sacred forest. For many years, this forest has been governed by local rules. Before Missouri Botanical Garden (MBG) began their conservation project of this sacred forest, the Tompontany (traditional owners of the forest) provided consent to protect the forest within other organizations, like WWF (1998-2002) and SAGE (2003-2006). The creation of the NPA Alandraza Agnalavelo, which received its final decree of legal protection in April 2015, can be considered an administrative process to strengthen the traditional protection of the Tompontany.

From the beginning of the NPA's creation, in 2007, the Tompontany have already agreed to protect Agnalavelo forest. Minutes containing their agreements are included in documents for the NPA's creation (Andriamihajarivo et al. 2008). The desires of Tompontany to enhance the cultural values of their forest, such as zebu sacrifice in the forest, were included within the document and were considered during the conservation process.

This study is part of an ongoing process, led by the Missouri Botanical Garden (MBG), aiming to establish a new protected area in Agnalavelo forest. While working with communities, MBG noticed that Agnalavelo is important to local livelihoods. Agnalavelo not only offers forest products and environmental services to the local communities, but it also supplies socio-cultural benefits to them. Goods and ecosystem services used and collected by the local population are highlighted in this study. They include: NonWood Forest Products (NWFPS) defined as "goods of biological origin other than wood, derived from forests, other wooded land and trees outside forest" (FAO 1999), wood products and other cultural benefits from the forest. The results of this study will be used as a tool to support decision making for Agnalavelo forest management.

Agnalavelo is a sacred forest to local people because they believe it to be a dwelling place for their ancestor's spirits (Horning 2004). Due to this fact, the local population has strict traditional rules to maintain the sacredness of the forest. However, Agnalavelo is still threatened by fires, illegal logging for house construction and hunting. Forests that are considered sacred may be better protected and less disturbed (Jones et al. 2008, Andriamarovololona and Jones 2012, Uyeda et al. 2014). The reinforcement of traditional authorities' power and integration of local rules in forest management would be among strategies to be considered within the Agnalavelo conservation plan.
The aim of this study was to determine goods and ecosystem services provided by the Agnalavelo forest to local people and to use it as a tool to identify priorities on forest conservation program. More precisely, we aimed to identify what benefits will be lost if Agnalavelo forest disappear.

\section{METHODS}

STUDY SITE. Agnalavelo forest is located in southwestern

Madagascar, in the district of Sakaraha; it is surrounded by the communes of Mahaboboka, Mikoboka and Amboronabo, bet-

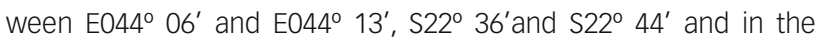
midst of an arid region (Figure 1). Due to its remoteness, entering the forest by crossing to Fiherenana River and hiking through mountains is very difficult. Thus, Agnalavelo forest can be considered a remote area distant from paved roads. It covers 4,044 ha (Andriamihajarivo 2014), on a volcanic basalt substrate, with a maximum elevation of $1350 \mathrm{~m}$ asl (Sourdat 1976). The climate in Agnalavelo forest is characterized by a sub-humid microclimate (Moat and Smith 2007), with an average rainfall of $1000 \mathrm{~mm}$ and a mean annual temperature of $20^{\circ} \mathrm{C}$ (Ferry and L'Hôte 1998). Agnalavelo forest is characterized by four types of vegetation, namely the humid forest, the sub-humid forest, the dry forest and the xerophytic bush formation (Randrianarivony 2015). They are hosts to many endemic species, such as lemurs (Propithecus verreauxi A. Grandidier, Microcebus murinus J. F. Miller and Cheirogaleus medius E. Geoffroy), other mammals (Microgale nasoloi Jenkins \& Goodman, Pteropus rufus Tiedemann and cryptoprocta ferox Bennett) (Soarimalala 2007, Andriamihajarivo et al. 2008), reptiles and birds (Neomixis viridis Sharpe, Foudia omissa Rothschild) (Raherilalao 2006). So far, 403 species of vascular plants grouped in 100 families and 249 genera were collected from the forest (Andriamihajarivo et al. 2008), 73\% of them are endemic to Madagascar. Three endemic plants families (Asteroperiaceae, Sphaerosepalaceae, Sarcolaenaceae) were inventoried (Andriamihajarivo et al. 2008). Two new plant species from Agnalavelo forest (Spondias tefyi J.D. Mitch., D.C. Daly and Randrian, Aloe analavelonensis Letsara, Rakotoarisoa and Almeda) were recently published (Mitchell et al. 2012, Letsara et al. 2012).

Nine ethnic groups (Bara, Antanosy, Antandroy, Masikoro, Vezo, Sakalava, Mahafaly, Betsileo and Antaisaka) live in the surrounding of Agnalavelo forest (Horning 2004). Bara is the respectful and the dominant ethnic group also called Tompontany, they are primarily cattle herders and farmers. The educational level is quite low in all villages surrounding the forest. Only people who live in

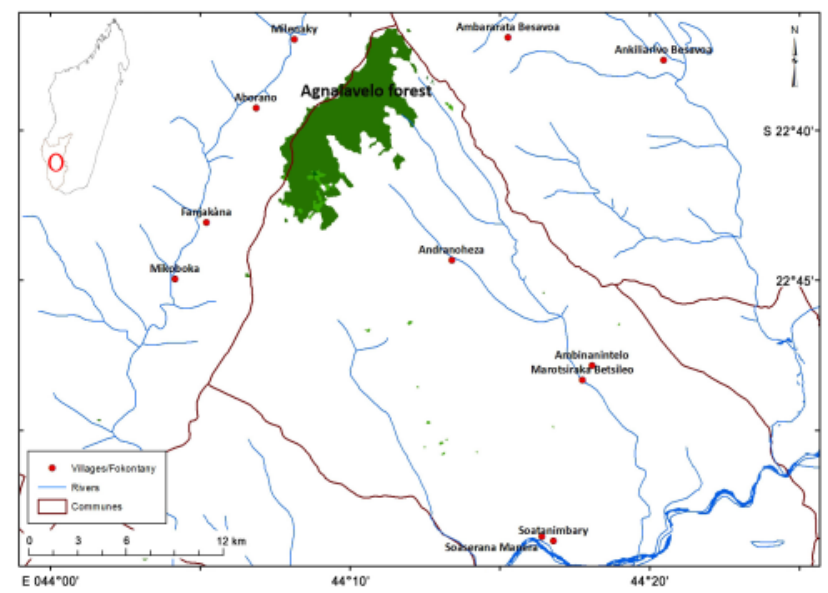

Figure 1. Localization of Agnalavelo forest. 
larger villages, namely Ambinanintelo and Soatanimbary (Mahabokoka), Besavoa (Amboronabo) and Fanjakàna and Soatanà (Mikoboka) have completed primary school. Even in these larger villages, only three teachers are responsible for all children at the primary school level. Educational infrastructure is grossly inadequate. In some villages like Soatanimbary and Besavoa; villagers' houses are used as classrooms. In Andranoheza, the classroom has been destroyed and Ambinanintelo do not have any classroom. Markets for food and goods exist only in the three rural communes (Mahaboboka, Amboronabo and Mikoboka). Churches are only found in Besavoa and in Fanjakàna. All houses in each village are adobe with roof of straw.

\section{DATA COLLECTION}

INTERVIEWS. Semi-structured oral interviews (Alexiades 1996) were performed from December 2010 to August 2011 in order to document all useful plants collected from Agnalavelo forest. Before conducting interviews, we obtained informed consent from administrative and traditional authorities as well as from each participant. Communities living in 34 villages from seven fokontany (lowest administrative subdivision in Madagascar) were selected for the survey. We randomly selected at least 50 individuals in each rural community including male and female participants who were between 15 and 81 years old. Spiritual healers, traditional healers, traditional midwives, carpenters and house builders were especially targeted as informants and a total of 259 informants were interviewed.

In addition, structured interviews (Grosshans and Chelimsky 1991) were performed in all villages in Andranoheza valley from June to September 2013. Heads of households, owner of rice fields irrigated by rivers sourced from Agnalavelo, were chosen as informants. Structured interviews were also conducted with community members who were known to harvest honey and those who used water from the forest for their daily needs. From these interviews, we were able to estimate the area of rice fields irrigated by water from Agnalavelo and to quantify the amount of honey potentially produced from hives in the forest (Appendix 1).

FOREST INVENTORIES. Tree species were recorded in order to

estimate the population of trees within the forest and get some other information, such as the volume of trees and useful trees and the species composition of the forest (Scott and Gove 2002). Forest inventories, carried out from August 2011 to March 2013 , were used also to assess the biomass of trees in the forest and to evaluate the carbon fluxes between aboveground forest ecosystems and the atmosphere (Houghton 2003, Grace 2004). Inventories were conducted in 11 plots of 0.1 hectares $(50 \mathrm{~m} \times 20 \mathrm{~m})$. The location of plots depended on the presence of species used and considered useful, such as wood for coffin, medicinal or magical plants, in Agnalavelo forest. Collection of data in each plot was done according to Braun-Blanquet methods (Poore 1955). Within each plot, we recorded the diameter at breast height (dbh) at $1.3 \mathrm{~m}$, and height at first branched for trees. These parameters were recorded with trees having diameters greater than or equal to $10 \mathrm{~cm}$, which is the usual minimum diameter considered in most inventories of woody forests. Specimens of unknown species were collected for identification. Dendrometric parameters such as density (Pascal 2003), basal area (Dawkins 1952, Gounot 1969), biovolume, aboveground tree biomass (Brown 1997), carbon stocks with aboveground biomass and the equivalent in se- questrated $\mathrm{CO} 2$ by Agnalavelo forest (Aalde et al. 2006, Mugnier et al. 2009) were estimated (Table S1).

LOGGING INVENTORY. This survey included identification of logged trees in the forest and determination of the reason for their logging. Three main trails in the eastern and western part of the forest were inspected. Furthermore, newly established trails in the forest were visited when local guides suspected them as potential indicators of new sites for logging. Reasons for logging were determined by inspecting the area around a cut tree. The opinions of local guides were taken into consideration during the assessment. The charred remains of wood, pieces of honeycombs and the presence of holes in the trunk were valuable clues that related to honey harvesting. Scattered bark was a good indicators for logging. The tree diameter was a crucial parameter considered in the case of tree logging for coffins. Local names of logged trees were given by local guides and their scientific names were determined by collecting left dried branches and leaves as vouchers.

MONETARY VALUATION OF GOODS AND ECOSYSTEM SERVICES. We assessed the relative worth of goods and ecosystem services from this forest (Farber et al. 2002). It has been argued that valuation of goods and ecosystem services is useless and does not correctly reflect the real significance of biodiversity (Heal 2000). However the Aichi targets for the new strategic plan for 2020, request that "values for biodiversity be integrated into national development strategies and national accounts" (Conservation on Biological Diversity 2011). Therefore assessment of the value of goods and ecosystem services of Agnalavelo forest could be integrated into the accounting system at a national level. Several methods have been developed by economists to evaluate goods and ecosystem services (Vuletić 2009, Groot et al. 2012), based on True Economic Value (TEV) in which goods and ecosystem services are divided into two categories: Use Value and Non-use Value (Aylward et al. 2003). For this study, we used market price (Aylward et al. 2003) of useful goods and ecosystem services provided by Agnalavelo forest. Real market prices were used to assign monetary value to goods and ecosystem services used by local people, such as: non-wood forest products (honey), crop (rice), carbon storage and water for irrigation and daily needs. Market value of carbon is however highly variable but we based our calculation on market values of carbon of Makira forest, in northeastern Madagascar, which is at $\$ 10$ per ton of carbon (Chappelle 2013).

\section{RESULTS}

PROVISIONING SERVICES. This category includes useful wood products, especially wood for coffins and other useful nonwood forest products. The non-wood forest products collected form Agnalavelo forest were food, raw botanical material for medicines, plant fibers, utensils, animal products such as honey, and meat from wild animals like tenrecs and lemurs. During the ethnobotanical survey, 350 useful species were cited by 259 informants. Among them, 65 species cited by 117 informants, were collected only from Agnalavelo forest. The other useful species were collected in dry forests and grasslands near the villages.

WOOD FOREST PRODUCTS. Three endemic species are harvested for coffins: Dalbergia purpurascens Baill. (Fabaceae), locally known as Magnary (Figure S1), Syzygium sakalavarum 
(H. Perrier) Labat \& G.E. Schatz called Rotsy and Albizia tulearensis R. Vig. called Mendoravy. Results from the forest inventory highlighted that mean height of Dalbergia purpurascens is $14 \mathrm{~m}$ with a standard error (SE) of 0.47 and could reach $20 \mathrm{~m}$ and its average $\mathrm{dbh}$ is $35 \mathrm{~cm}( \pm 3.35 \mathrm{SE})$ and sometimes could reach $1 \mathrm{~m}$, with a mean density of about 38 individuals/ha $( \pm 27.32 \mathrm{SE}$ ) and a mean aboveground biomass of 37 tons/ha ( \pm 0.19 SE). In 2016, the cost of a coffin is about $\$ 180(\sim$ MGA540,000 at the time of this research) on average, equivalent to 8 months of wages for people living in the surroundings of the forest. By having access to resource from Agnalavelo forest, local people can save this amount at funeral time. From 2013 to 2015, we have recorded 12 deaths for which coffins were made from wood taken from Agnalavelo forest. Whether Agnalavelo forest is a protected area, collecting Magnary as wood for coffin in this forest is part of local people's right. Eighteen tree species cited by 38 informants were illegally collected from Agnalavelo forest for house construction. From inventory of logged trees, we found 55 stumps of Zanthoxylum tsihanimposa H. Perrier (Rutaceae), Erythroxylum firmum Baker (Erythroxylaceae), and Capurodendron gracilifolium Aubrév. (Sapotaceae) and Viguieranthus ambongensis (R. Vig.) Villiers (Fabaceae) logged and used in house buildings (Figure S2).

NON-WOOD FOREST PRODUCTS. Food: Tubers of two wild species of Dioscorea, i.e. D. soso Jum. \& H. Perrier, and D. ovinala Baker (Dioscoreaceae) are harvested in the forest when men keep their cow there. These species are also highly sought during hunger period. Fruits of Sygyzium sakalavarum (Myrtaceae), Adansonia za Baill. (Malvaceae) and Spondias tefyi (Anacardiaceae) were collected as edible.

Raw material for medicines: Thirty-one species were cited by 69 informants as medicinal plants, among which, 12 species cited by, at least 4 informants: Vepris unifoliolata (Baill.) Labat, M. Pignal \& O. Pascal, Emilia humifusa DC., Suregada eucleoides Radcl.-Sm., Celtis gomphophylla Baker, Toddalia asiatica (L.) Lam., Ocotea trichantha Baker, Gouania pannigera Tul., Strychnos henningsii Gilg, Rinorea greveana Baill., Ensete perrieri (Claverie) Cheesman and Piper cf. borbonense (Miq.) DC. (Figure S2). Toddalia asiatica (Rutaceae), Strychnos henningsii (Loganiaceae) were cited by more than 15 informants for the treatment of digestive system disorders, by grinding the stems into powder to be used as infusion for the stomach-ache and belly-ache.

Utensils: Nine species cited by 16 informants were used for tool handles: Wielandia bojeriana (Baill.) Petra Hoffm. \& McPherson (Euphorbiaceae). A hard slender wood locally known as Tsifolaboay was frequently cited for this purpose.

Fiber: Bark of Bauhinia decandra Du Puy \& R. Rabev. (Fabaceae) and Spondias tefyi (Anacardiaceae) were used to produce rope during visits to the forest. Two individuals of $B$. decandra were found debarked during the inventory.

Products from animals: Tenrec ecaudatus Schreber, locally known as Sora, wild birds Voro and lemurs (Propithecus verreauxi, Lemur catta, Eulemur rufifrons) locally known as Sifaky, are illegally hunted in the forest (Figure S3). They are believed to be fatty and delicious meat for villagers during hunger periods. Moreover, people may hunt these animals because killing a zebu is too expensive and zebus are highly valued by local people. Six households from Mikoboka village practice illegal lemur hunting in Agnalavelo forest twice a month, from September to January each year. A group of four men normally hunt four to eight lemurs for local consumption during each hunting session.

Honey production: honey, locally known as Antely is collected in Agnalavelo forest from March to July for consumption and also for local sale. Bees are found in holes of felled or living trees (Figure S4). Big trees with a dbh averaging $50 \mathrm{~cm}$, such as Ocotea trichantha and Euphorbia mandravioky often contained honeycombs. We inventoried 25 individuals of endemic species such as Rinorea greveana, Ocotea trichantha, Capurodendron gracilifolium, vitex lanigera and Euphorbia mandravioky felled down during honey harvesting. The quantity of honey collected in the forest was approximately 20 liters/household/month during the harvesting period. Selling of wild honey ( $\$ 1$, MGA3000/liter), was a part-time activity of $4 \%$ of households $(n=12)$. Five households collected honey in the forest twice a year and the remaining once a year. When local consumption is taken into account, honey production of the Agnalavelo forest is estimated at 350 liters/year and brought $\$ 350 /$ year ( MGA1,050,000) to local people.

Fresh water supply: five rivers (Manadabo, Manasay, Betaola, Andranoheza and Sakalomory) take their source from Agnalavelo forest. Domestic water and water used for irrigation of crop fields at Andranoheza valley are supplied by these rivers. Because water sourced from Agnalavelo is drinkable, fresh water for domestic use is obtained straight from river. This is particularly important as it contributes to water procurement to villages during the dry season. A total of 288 households, with an average of eight persons per household, consumed 60 liters per household per day. About 1200 ha of rice fields in Andranoheza valley were irrigated with river water from Agnalavelo forest. Those rice fields produce about 2000 tons of rice per year as some villagers harvest twice a year (production of 1.5 ton per hectare of rice). Water process in Madagascar vary from at $\$ 0.2 / \mathrm{m}^{3}$ (in Antananarivo, from the national company that manages water and electricity to households JIro sy RAno MAlagasy or JIRAMA) to $6.25 \$ / \mathrm{m}^{3}$ for people in dry regions who pay water fetched by day laborers. In our site study, the income from irrigated field was estimated as three times the income from a non-irrigated one. This adds value to services using water from Agnalavelo forest.

CULTURAL SERVICES. Local people strongly believe that

Agnalavelo forest was a hiding place for their parents during the colonization period, to escape from mandatory labor. They believe that their ancestor's spirits stay in the forest. After independence, village elders, especially the head of village (Lonaky) and spiritual healers (Ombiasy), acknowledge services rendered by the forest by saving their ancestors from persecution and declared it a place of worship. Ancestor's spirit living in the Agnalavelo forest became advisors to spiritual healers for the uses of plants. Therefore, local people believe that part of their blessings and their success for agricultural activities comes from the forest.

A large part of informants, $90 \%$ of 259 informants interviewed during surveys, confirmed that they were aware of Agnalavelo forest sacredness. These informants considered Agnalavelo as a place where they can communicate with their ancestor. They describe it as a living forest that gives life and foods, brings success and is also a source of healing and protection. Thirty-four informants (26 male and 8 female) reported taboos in Agnalavelo forest, which included taking pork meat, gold and silver jewelry and kitchen utensils to the forest, not respecting the cleanliness of the forest and having sexual intercourse in the forest. Thirtyone informants (27 male and 4 female) underlined the need of 
worship and veneration of the ancestor prior to any activities in the forest. People who worked in the forest must bring a zebu, red rum, perfumed scent, perfumed oil, tobacco, money or a black cock as gifts or sacrifices to the ancestor's spirits, depending on their activities. The Lonaky have specified that collection of wood for coffins must be preceded by a zebu sacrifice, otherwise ancestor's spirits would be displeased and could kill another villager. Similarly, the Lonaky stated that if there was no sacrifice of zebu in Agnalavelo forest the rain would be scarce during the year.

Thirty-seven plant species cited by 67 informants were collected from Agnalavelo forest for cultural purposes. Those plants were believed to possess magical properties and are referred as "magical plants" in this study. The use of those magical plants helped local people to beg their ancestor for blessings (fitahy), for disenchantments (fanalaha voriky), success in their agricultura activities (fieboa), to get more power within the community (fandrorota), protection against bad spells, bandit attacks, bad weather and misfortune (fiaro), to charm girls, women or men (aoly lahy, aoly ampela) and to bring fertility to women who could not have children (fananan'anaky). More than six informants reported that the following plant species were used for cultural purposes: suregada eucleoides, Tannodia cordifolia Baill., Ocotea trichantha, Dracaena xiphophylla Baker, Albizia tulearensis, Vepris boiviniana (Baill.) Mziray, Vepris unifoliolata, Artabotrys madagascariensis Miq. and Drynaria willdenowii (Bory) T. Moore (Table S2). A talisman containing stem powder of Suregada eucleoides was believed to give power and to bring success to its users. Ocotea trichantha was used to confer fertility to women who could not have children. Dracaena xiphophylla was used to improve the user's seductive ability and raise the chance to attract future spouse.

The bark of Ficus tiliifolia Baker (Moraceae) was made into clothing in the past. The branches and leaves of Wielandia elegans (Phyllanthaceae) were used for soap.

EDUCATIONAL VALUE. Agnalavelo forest is well-preserved; and national and foreign researchers are still investigating its flora and fauna. Students from local primary and secondary schools in Mahaboboka have participated in environmental education within the conservation project of Agnalavelo forest. Students were trained about biodiversity found in dry and sub-humid forest and their conservation.

REGULATING SERVICES. According to the results of forest inventories, the number of trees in each plot varied from 65 to 127 with an average of 104 trees ( \pm 6.69 SE). Tree density in Agnalavelo forest was on average 1038 individuals/ha ( $\pm 6.69 \mathrm{SE}$ ), with an average height of $12 \mathrm{~m}$ ( $\pm 0.09 \mathrm{SE}$ ) and an average dbh of $20 \mathrm{~cm}$ ( $\pm 0.44 \mathrm{SE}$ ). The basal area of Agnalavelo forest was estimated at $47 \mathrm{~m}^{2} / \mathrm{ha}( \pm 0.003 \mathrm{SE}$ ). The assessment of aboveground biomass yielded 321 tons ( $\pm 0.03 \mathrm{SE}$ ) per hectare, with 152 tons of carbon per hectare stored by living material, which is equivalent to 559 tons of $\mathrm{CO}_{2}$ sequestrated per hectare. This study showed about $\$ 6$ million benefits associated with conservation due to carbon storage values. The function of the natural forest ecosystem to regulate water flow and rain frequency could decrease the impacts of climate change in the surroundings of Agnalavelo forest and at national level. Finally, during our study, we observed that flowers, especially Argomuellera Pax (Euphorbiaceae), are used by bees as a source of nutrients.

\section{DISCUSSION}

This study highlights that goods and ecosystem services from Agnalavelo forest provide an important contribution to local people's wellbeing, such as provisioning, cultural and regulating services. Before the establishment of protected areas, forests were considered as fertile land for slash and burn activities locally called Hatsaka (Milleville et al. 2001, Blanc-Pamard 2002, Aubry and Ramaromisy 2003). They also provide timber, firewood and charcoal (Dirac Ramohavelo 2009, Grafl et al. 2009). As Agnalavelo is a sacred forest, the local rules forbid slash and burn activities, collection of timber for construction and exploitation of timber for fuel and charcoal inside the forest. However, they can perform some activities like collection of medicinal and magical plants and plants for tool handles when visiting the forest for other reasons. The quantity of medicinal and magical plants and food collected in the forest is low and seems to not negatively impact species survival or lead to ecosystem degradation (Randrianarivony 2015).

Agnalavelo forest is classified as a category III (Natural Monument) protected area by IUCN. It is a place where people are traditionally permitted some forest access for collecting wood for coffin, honey, medicinal and magical plants in the forest. Local rules called Dina and management plans have been established and are generally effective. Unlike in other parts of Madagascar (Menabe Central Region, Manompana corridor) (Dirac Ramohavelo 2009, Urech et al. 2012), trade of goods and services (charcoal, food and honey) is not an important source of income for local population around Agnalavelo forest. Trade of honey harvested from the forest represents a very low income. Nevertheless, honey collection can become problematic as many trees were felled for this purpose. Banning honey collection for sale was recently included in the management plan of Agnalavelo forest (Andriamihajarivo 2014). Moreover, local people are not allowed to cut trees during honey collection, so introduction of tools such as harness and ropes to honey collectors is needed, then a beekeeping project needed to be established for the local population (Randrianarivony 2015).

Timber harvesting for coffins is the most important service that local people benefit from Agnalavelo forest. No trade of wood was observed from surroundings of Agnalavelo compared to trade of precious wood such as rosewood and ebony from the SAVA region in northeastern Madagascar (Randriamalala and Liu 2010).

Lemurs were hunted and eaten by $2 \%$ of households surrounding the Agnalavelo forest. This rate is relatively low compared to data reported from other regions in Madagascar, with 17\% of households in Betampona and to $49 \%$ in Makira (Golden et al. 2014). However, in 1972, Griveaud and Peyrieras observed more than five groups of four Propithecus verreauxi a day in Agnalavelo forest, but 40 years later, we only recorded one group of two Propithecus verreauxi a day. This suggests that hunting activities may have reduced the number of lemurs in the forest.

A huge quantity of rice is produced from fields in Andranoheza valley; however, we noticed that local people still have difficulty finding food during dry season. This fact is due to the custom of Bara people to give high importance to zebu. During rice harvesting period, people sell $2 / 3$ of their production to buy cattle or exchange rice for cattle.

Taboos, cultural and ritual values of forests or species are common to many forest patches throughout Madagascar. As the case of forest in the Central Menabe and forest patches in the 
Androy Region (Tengö et al. 2004, Dirac Ramohavelo 2009), Agnalavelo forest is a place where Tompontany believe they receive instructions from their ancestors and where most plant species for talismans and for magical remedies are collected. Since Bara in that region believe that Agnalavelo is a dwelling place of their ancestor's spirits (Horning 2004), cultural services from the forest play important roles in customs and ritual ceremonies.

Contrary to other studies undertaken worldwide and in Madagascar (Jones et al. 2008, Dudley et al. 2009, Uyeda et al. 2014), there are neither plant nor animal species or sacred groves in Agnalavelo forest that are taboos for hunting or for collection. The forest is entirely sacred, and the southeast part of the forest (Ankokoky) is the most sacred site where zebu sacrifice must take place. Horning (2004) reported on prohibited, permitted and prescribed activities in the Agnalavelo forest and found that people from Andranoheza valley and villagers from Amboronabo paid more attention on obeying rules. Our data on forest structures (unpublished) indicates that threats and pressures on the forest begin to be visible in the southwest part of the massif, near Mikoboka. Immigrants, who have settled in Mikoboka, do not believe anymore in the sacredness of the forest, illegally collect wood for construction and illegally hunt lemurs in the forest. Like in other sacred sites (Dirac Ramohavelo 2009, Dudley et al. 2009, Bhagwat and Rutte 2006), traditional values and sacredness of Agnalavelo forest is being challenged by the arrival of immigrants and evangelist Christians that are opposed to worshipping of ancestor as idolatry, and by the arrival of westernized culture, which affects the younger generation. Local youths are influenced by the use of modern medicine and use of the technology in communication.

The role of sacredness and taboos in conservation is widely accepted in Madagascar (Fauroux 1997, Lingard et al. 2003, Cinner 2007) and elsewhere (Tengö et al. 2004, Dudley et al. 2009). Thus, integrating traditional authority in conservation strategy by enforcing traditional rules and the power of Lonaky should be considered in the management plan of Agnalavelo forest, and everybody should strictly follow traditional rule prior to any activities in the forest.

Some studies were undertaken to estimate values for the carbon storage functions of rainforests; for example in Makira, Zahamena-Mantadia, Tsitongambarika and Congo forests (Meyers 2001, Hockley and Razafindralambo 2006, Nasi et al. 2009, Olsen et al. 2011). Estimated carbon that Agnalavelo forest (152 tons of carbon per hectare) can stock is quite similar to that estimated by Hockley and Razafindralambo (2006) for the Zahamena-Mantadia Corridor (148 tons of carbon per hectare) but lower than carbon stocks in Makira (286 tons/ha) found by Meyers (2001), in Tsitongambarika III (200 tons/ha) estimated by Olsen et al. (2011) and in Congo forest (185 tons/ha) by Nasi et al. (2009). Because most trees in Agnalavelo are tall, we expected that Agnalavelo had the highest estimate of carbon stocks in this southwestern part of Madagascar. Recreational value is lower than that reported in Groot et al. (2012) because Agnalavelo forest is located in a remote area. Value of hydraulic services and biodiversity from Agnalavelo forest is important in this dry southwestern part of Madagascar. Regarding the use of medicinal plants from the forest, botanical materials for medicine are mostly collected in dry forest and in remnant forests near villages.

In the present study, the estimation of carbon stocks is a gross value. It does not include $\mathrm{CO}_{2}$ emission caused by fires to increase grazing areas, and some agricultural activities already discussed (Cairns 2002). The valuation of services and goods does not take the conservation effort by stakeholders into account, nor the time spent during the collection of provisioning services in the forest.

\section{CONCLUSIONS}

Apart from ecological and cultural services, Agnalavelo forest provides provisioning services (water, beehives and coffins) at local, regional and national levels. Associated conservation benefits (carbon storage, honey collection and water for irrigation of Andranoheza valley) demonstrate why the conservation of Agnalavelo forest is important.

Agnalavelo forest is the best candidate for carbon sequestration in southwestern Madagascar and villagers living in the vicinity of the forest could benefit from a community-driven development program, using the money from the sale of carbon credits. The data related to valorization of services could be helpful for decisionmaking, and also as a tool for environmental education. The assessment of services from Agnalavelo forest illustrates the contribution of ecosystems to social and economic wellbeing.

According to local belief, some plants are considered as magic and having supernatural effects because they grow in a sacred place. Local villages receive protection from their ancestor by using those magic plants. The sacredness of Agnalavelo forest must be emphasized to visitors of the forest and to immigrants. We suggest education programs about goods and ecosystem services from Agnalavelo forest to encourage people to adhere again to traditional rules.

Most of services such as NWFP, biodiversity and cultural services are non-market services, even if some products (e.g., honey) are intended for sale in the local market. Those non-market services are highly valued by local communities and are part of their cultural identity.

\section{ACKNOWLEDGEMENTS}

The authors acknowledge the important contribution of the local population of Agnalavelo forest for the surveys. We are grateful to the active collaboration of Miandry Fagnarea, Rehary and Rebesa for some data collection. We acknowledge the William L. Brown Center (MBG) Benefica and National Geographic Society (NGS) foundation for financial support. We highly acknowledge all University members and MBG's staff supports during the realization of this work.

\section{REFERENCES}

Aalde, H., Gonzalez, P., Gytarsky, M., Krug, T., Kurz, W. A., et al. 2006. Lignes directrices 2006 du GIEC pour les inventaires nationaux de gaz à effet de serre: Agriculture, foresterie et autres affectations des terres. Institute for Global Environnemental Strategies 4, 4: 1-93.

Alexiades, M. N. 1996. Collecting ethnobotanical data: An introduction to basic concepts and techniques. In: Selected Guidelines for Ethnobotanical Research. M. N. Alexiades (ed.), pp 53-94. The New York Botanical Garden, New York.

Andriamarovololona, M. M. and Jones, J. P. G. 2012. The role of taboos and traditional beliefs in aquatic conservation in Madagascar. In: Sacred Species and Sites: Advances in Biocultural Conservation. G. Pungetti, G. Oviedo, D. Hooke (eds.), pp 207-217. Cambridge University Press, Cambridge UK. (doi:10.1017/CBO9781139030717.021)

Andriamihajarivo, T. H. 2014. Document de création définitive, Nouvelle aire protégée: forêt sacrée Analavelona. Unpubl. report to Missouri Botanical Garden. (available as Supplementary Material) 
Andriamihajarivo, T. H., Ravoahangy, A., Rakotoarison, T. \& Andrianarinala, M. 2008. Evaluation biologique et sociologique en vue de création en Nouvelle aire protégée de la forêt sacrée d'Analavelona - Sakaraha. Unpubl. report to Missouri Botanical Garden. (available as Supplementary Material)

Aubry, C. and Ramaromisy, A. 2003. Typology of farms in a village of the pioneer settlement area of the Mikea Forest (South West of Madagascar). Cahiers Agriculture 12 3: 153-165.

Aylward, B., Bann, C., Barbier, E., Bishop, J., Burgess, J., Collins, M., Eaton, D., Landell-Mills, N., Reynolds, F., Saunders, J. and Young, C. 2003. Valuing Forests: A Review of Methods and Applications in Developing Countries. Environmental Economics Programme, International Institute for Environment and Development (IIED), London. Available at $<$ http://pubs.iied.org/8116llED.html>

Bhagwat, S. A. and Rutte, C. 2006. Sacred groves: potential for biodiversity management. Frontiers in Ecology and the Environment 4, 10: 519-524. (doi:10.1890/1540-9295(2006)4[519:SGPFBM]2.0.CO;2)

Blanc-Pamard, C. 2002. La forêt et I'arbre en pays masikoro (Madagascar) : un paradoxe environnemental ? Bois et Forêts des Tropiques 271, 1: 5-22.

Brown, S. 1997. Estimating Biomass and Biomass Change of Tropical Forest: A Primer. FAO Forestry Department, Rome, Italy. Available at <http://www.fao.org/docrep/w4095e/w4095e00.htm>

Cairns, R. D. 2002. Green accounting using imperfect, current prices. Environment Development Economy 7, 2: 207-214. (doi:10.1017/S1355770X02000141)

Chappelle, S. 2013. Quand des ONG Environnementales veulent vendre des Crédits Carbones. Available at <www.bastamag/décrypter/quand-des-ong-environnementalesQ>

Cinner, J. E. 2007. The role of taboos in conserving coastal resources in Madagascar. SPC Traditional Marine Resource Management and Knowledge Information Bulletin 22: 15-23. Available at <http://www.spc.int/Coastfish/News/Trad/22/Trad22_15_Cinner.pdf>

Conservation on Biological Diversity (CBD). 2011. The strategic plan for biodiversity 2011-2020 and the Aichi targets. Montréal, Québec, Canada. Available at $<$ https://www.cbd.int/sp/>

Dawkins, H. C. 1952. Experiments in low percentage enumerations of tropical high forest with special reference to Uganda. Empire Forestry Review 31, 2: 131-149. Available at <http://www.jstor.org/stable/42599474>

Dirac Ramohavelo, D. 2009. Stratégies villageois pour la gestion des paysages forestiers du Menabe Central, Madagascar. Thèse de Doctorat. École Polytechnique Fédérale de Lausanne, Suisse. Available at $<$ http://ow.ly/uZ3q302Jxjb>

Dudley, N., Higgins-Zogib, L. and Mansourian, S. 2009. Links between protected areas, faiths and sacred natural sites. Conservation Biology 23, 3: 568-577. (doi:10.1111/j.1523-1739.2009.01201.x)

Farber, S. C., Costanza, R. and Wilson, M. A. 2002. Economic and ecological concepts for valuing ecosystem services. Ecological Economics 41, 3: 375-392. (doi:10.1016/S0921-8009(02)00088-5)

Fauroux, E. 1997. Les représentations du monde végétal chez les Sakalava du Menabe. In: Milieux et Sociétés dans le Sud-ouest de Madagascar. J.-M. Lebigre, E. Fauroux, B. Moizo, J. Taillade, P. Vasseur, C. Henry-Chartier, P. Henry (eds.), pp 7-26. Presses Universitaires de Bordeaux, Bordeaux, France.

Ferry, L. \& L'Hôte, Y. 1998. Les précipitations dans le sud-ouest de Madagascar. In: Water Ressources Variability in Africa during the 20th Century. E. Servat, D. Hughes, J.-M. Fritsch, M. Hulme (eds.), pp 89-96. AISH, Wallingford. Available at <http://www.documentation.ird.fr/hor/fdi:010017930>

FAO (Food and Agriculture Organization). 1999. Non Wood Forest Product and Income Generation. Dembner, S.A., Perlis, A. (eds.). Unasylva - No. 198. Available at http://www.fao.org/docrep/x2450e/×2450e00.htm\#Contents.

Golden, C. D., Rabehatonina, J. G. C., Rakotosoa, A. and Moore, M. 2014. Socioecological analysis of natural resource use in Betampona Strict Natural Reserve. Madagascar Conservation \& Development 9, 2: 83-89. (doi:10.4314/mcd.v9i2.4)

Gounot, M. 1969. Méthode d'Étude Quantitative de la Végétation. Masson, Paris.

Grace, J. 2004. Understanding and managing the global carbon cycle. Journal of Ecology 92, 2: 189-202. (doi:10.1111/j.0022-0477.2004.00874.x)
Graf, E. Andriambelo, L. H. and Sorg, J.-P. 2009. Ecological and social issues: Availability and uses of four timber tree species in Menabe, Madagascar. Bois et Forêts des Tropiques 302, 4: 33-41.

Griveaud, P. and Peyrieras, A. 1976. Compte-rendu des missions R.C.P. 225 de mai-juin 1972 dans les massifs de I'Andohahelo et de l'Analavelo. Madagascar, Revue de Géographie 27: 101-119.

de Groot, R., Brander, L., van der Ploeg, S., Costanza, R., Bernard, F., et al. 2012. Global estimates of the value of ecosystems and their services in monetary units. Ecosystem Services 1, 1: 50-61. (doi:10.1016/j.ecoser.2012.07.005)

Grosshans, W. and Chelimsky, E. 1991. Using Structured Interviewing Techniques. United States General Accounting Office, Program Evaluation and Methodology Division, Washington DC. Available at <http://www.gao.gov/products/PEMD-10.1.5>

Heal, G. 2000. Valuing ecosystem services. Ecosystems 3, 1: 24-30. (doi:10.1007/s100210000006)

Hockley, N. J. and Razafindralambo, R. 2006. A Social Cost-Benefit Analysis of Conserving the Ranomafana-Andringitra-Pic d'Ivohibe Corridor in Madagascar. Unpubl. Report to USAID/Madagascar. Available at <http://citeseerx.ist.psu.edu/viewdoc/summary?doi=10.1.1.605.7055>

Horning, N. R. 2004. The Limits of Rules: When Rules Promote Forest Conservation and When They Do Not - Insights from Bara Country, Madagascar. PhD thesis, Department of Government Cornell University, NY. Available at <http://OW.ly/fv7W302JK8H>

Houghton, R. A. 2003. Why are estimates of the terrestrial carbon balance so different? Global Change Biology 9, 4: 500-509. (doi:10.1046/j.13652486.2003.00620.x)

Jones, J. P. G., Andriamarovololona, M. M. and Hockley, N. 2008. The importance of taboos and social norms to conservation in Madagascar. Conservation Biology 22, 4: 976-986. (doi:10.1111/j.1523-1739.2008.00970.x)

Letsara, R., Rakotoarisoa, S. and Almeda, F. 2012. Three new Aloe species from Madagascar. Malagasy Nature 6: 46-55.

Lingard, M., Raharison, N., Rabakonandrianina, E., Rakotoarisoa, J.-A., Elmqvist, T. 2003. The role of local taboos in conservation and management of species: the radiated tortoise in southern Madagascar. Conservation and Society 1 , 2: $223-246$.

Meyers, D. 2001. Makira Forest Project Madagascar. Report for MEF-IRG/PAGEUSAID. Available from <http://ow.ly/BOPT302JMjD>

Milleville, P., Grouzis, M., Razanaka, S. \& Bertrand, M. 2001: La culture pionnière du maïs sur abattis-brûlis (Hatsaky) dans le sud-ouest de Madagascar : 2. Évolution et variabilité des rendements. In: Sociétés Paysannes, Transitions Agraires et Dynamiques Écologiques Dans le Sud-ouest de Madagascar. . S. Razanaka, M. Grouzis, P. Milleville, B. Moizo, C. Aubry (eds.), pp 255-268. CNRE \& IRD, Antananarivo, Madagascar.

Mitchell, J. D., Daly, D. C. and Randrianasolo A. 2012. The first report of Spondias native to Madagascar: Spondias tefyi, sp. nov. (Anacardiaceae). Brittonia 64, 3: 263-267. (doi:10.1007/s12228-011-9231-Z)

Mittermeier, R. A., Hawkins, F., Rajaobelina, S. and Langrand, O. 2005. Wilderness Conservation in a Biodiversity Hotspot. International Journal of Wilderness 11, 3: 42-45.

Moat, J. and Smith, P. 2007. Atlas of the Vegetation of Madagascar. Kew Publishing, Royal Botanic Gardens, Kew.

Mugnier, A., Cassagne, B., Bayol, N. and Lafon, C. 2009. Estimation des stocks de carbone des forêts du bassin du Congo pour le REDD, étude comparative conduite sur 22 types forestiers, 4 pays et un dispositif d'aménagement de 4,8 millions d'ha. Unpubl. XIlle Congrès Forestier Mondial, Buenos Aires, Argentine.

Nasi, R., Mayaux, P., Devers, D., Bayol, N., Eba'a Atyi, R., et al. 2009. Un aperçu des stocks de carbone et leurs variations dans les forêts du bassin du Congo. In: Les Forêts du Bassin du Congo. C. De Wasseige, D. Devers, P. De Marcken, R. Eba'a Atyi, R. Nasi, P. Mayaux, (eds.), pp 199-216. Office des Publications de l'Union Européenne, Luxembourg

Olsen, N., Bishop, J. and Anstee, S. 2011. Exploring Ecosystem Valuation to Move Towards Net Positive Impact on Biodiversity in the Mining Sector. IUCN and Rio Tinto Technçical Series, Gland, Switzerland \& London.

Pascal, J.-P. 2003. Notions sur les structures et dynamique des forêts tropicales humides. Revue Forestière Française 55: 118-130. (doi:10.4267/2042/5765) 
Poore, M. E. D. 1955. The use of phytosociological methods in ecological investigations: 1. The Braun-Blanquet system. Journal of Ecology 43, 1: 226-244. (doi:10.2307/2257132)

Raherilalao, M. J. 2006. Contribution à la Connaissance de la Biogéographique des Oiseaux Forestiers des Hautes Terres Malgaches. Unpubl. Thèse de doctorat, Université d'Antananarivo, Madagascar.

Randriamalala, H. and Liu, Z. 2010. Rosewood of Madagascar: Between democracy and conservation. Madagascar Conservation \& Development 5, 1: 11-22. (doi:10.4314/mcd.v5i1.57336)

Randrianarivony, T. N. 2015. Etudes Ethnobotaniques et Écologiques des Plantes Utiles de la Nouvelle Aire Protégée d'Analavelona (District de Sakaraha) Unpubl. Thèse de doctorat, Université d'Antananarivo, Madagascar.

Sarrasin, B. and Ramahatra, H. 2006. Biodiversité et logique du développement « par » et « pour » l'écotourisme à Madagascar. Centre Tricontinental, Louvain-la-Neuve, Belgium. Available at <www.cetri.be/spip.php?article187>

Scott, C. T. and Gove, J. H. 2002. Forest Inventory. Encyclopedia of Environmetrics 2: 814-820. John Wiley \& Sons Ltd, Chichester, UK.

Soarimalala, R. A. L. 2007. Contribution à l' Étude Biogéographique des Petits Mammifères Non Volants des Hautes Terres Malgaches. Unpubl. Thèse de doctorat, Université d'Antananarivo, Madagascar.

Sommerville, M., Milner-Gulland, E. J., Rahajaharison, M. and Jones, J. P. G. 2010. Impact of a community-based payment for environmental services intervention on forest use in Menabe, Madagascar. Conservation Biology 24, 6: 1488-1498. (doi:10.1111/j.1523-1739.2010.01526.x)

Sourdat, M. 1976. Le Sud-ouest de Madagascar, étude géodynamique. Cahiers ORSTOM, série Pédologie 14, 3: 245-251.

Tengö, M., Johansson, K., Rasoarisela, F., Lundberg, J., Andriamaherilala, J.-A., et al. 2004. Local protection of tropical dry forest: taboos and ecosystem services in southern Madagascar. In: Management Practices for Dealing with Uncertainty and Change: Social-Ecological Systems in Tanzania and Madagascar. M. Tengö. Unpubl. PhD thesis, Stockholm University, Sweden. Available at $<$ http://www.diva-portal.org/smash/record.jsf?pid=diva2\%3A192295\&dswid=article>

UNESCO. 2012. Document UNESCO de Programmation Pays : Madagascar 2012-2013. Available at <http://ow.ly/lqyN302JUBV>

Urech, Z. L., Felber, H. R. and Sorg, J-P. 2012. Who wants to conserve remaining forest fragments in the Manompana corridor? Madagascar Conservation \& Development 7, 3: 135-143. (doi:10.4314/mcd.v7i3.6)

Uyeda, L. T, Iskandar, E., Purbatrapsila, A., Pamungkas, J., Wirsing, A. and Randall, C. K. 2014. The role of traditional beliefs in conservation of herpetofauna in Banten, Indonesia. Oryx 50, 2: 296-301. (doi:10.1017/S0030605314000623)

Vedeld, P., Angelsen, A., Bojö, J., Sjaastad, E. and Kobugabe Berg, G. 2007. Forest environmental incomes and the rural poor. Forest Policy and Economics 9, 7: 869-879. (doi:10.1016/j.forpol.2006.05.008)

Vuletić, D., Benko, M., Dubravac, T., Krajter, S., Novotny, V., et al. 2009. Review of non-market forest goods and services evaluation methods. Periodicum Biologorum 111, 4: 515-521.

Wendland, K. J., Honzák, M., Portela, R., Vitale, B., Rubinoff, S. and Randrianarisoa, J. 2010. Targeting and implementing payments for ecosystem services: Opportunities for bundling biodiversity conservation with carbon and water services in Madagascar. Ecological Economics 69(11): 2093-2107. Available at <http://hrcak.srce.hr/file/73939>

Westman, W. E. 1977. How much are nature's services worth? Science 197: 960-964. (doi:10.1126/science.197.4307.960)

World Resources Institute (WRI). 2005. Millennium Ecosystem Assessment: Ecosystems and Human Well-being: Synthesis. Island Press, Washington, DC. Available at <http://OW.ly/PR1Y302JWvf>

Wu, S., Hou, Y. and Yuan, G. 2010. Valuation of forest ecosystem goods and services and forest natural capital of the Beijing municipality, China. Unasylva 61, 1: 28-36.

\section{SUPPLEMENTARY MATERIAL.}

Available online only.

Appendix 1. Questionnaire guide used during the oral interview.

Table S1. Equations for the estimation of each dendrometric factor Table S2. List of the most useful species from Agnalavelo sacred forest.

Figure S1. A: Cut Magnary for coffin in Agnalavelo forest (photo by Tabita N. Randrianarivony); B: coffin made by Magnary (photo by Tefy H. Andriamihajarivo).

Figure S2. Wood illegally collected for house construction in Agnalavelo forest (photo by Tabita N. Randrianarivony).

Figure S3. Dead body of a lemur in the forest. (photo by Tefy $\mathrm{H}$. Andriamihajarivo).

Figure S4. Tree as beehive with honey in the Agnalavelo forest. (photo by Tabita N. Randrianarivony). 